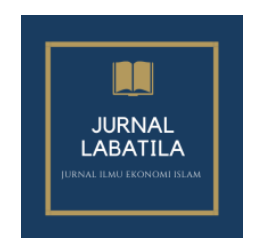

LABATILA: Jurnal Ilmu Ekonomi Islam

Volume 04, Nomor 01 (2020)

Fakultas Ekonomi dan Bisnis Islam IAINU Kebumen

e-ISSN: 2621-3818 p-ISSN: 2614-6894

https://doi.org/10.33507/lab.v4i01

\title{
UNDIAN DAN LOTERE DALAM PERSPEKTIF MASAIL AL-FIQHIYYAH
}

\author{
Mukhsinun \\ Institut Agama Islam Nahdlatul Ulama Kebumen \\ mukhsinun.kebumen@gmail.com
}

\begin{abstract}
Lottery was a custom that had been in force long before Islam came, but the lottery that prevailed during the jahiliyyah period was to determine a person's good and bad luck and was carried out in front of their idols. However, for current conditions, lotteries are often carried out in the world of trade with the aim of making consumers interested in the goods they offer. The lottery or lottery of luck is both largely determined by fate. The implementation can be done by individuals, companies or institutions. The purpose of both is usually indicated to raise funds in an effort to improve the marketing of trading products. This type of research is library research. The method used to analyze it is content analysis, because this research is document analysis. The approach used is maqasid sharia. Basically, lotteries and lotteries are almost the same, as for the fundamental difference between the two, namely in the lottery there is an element of gambling that is forbidden, namely winning and losing or profit and loss, while in the lucky draw that is developing today there is no element of loss that is forbidden as a result in gambling. In a lucky draw neither party is harmed so there is no term that one party eats the other party's property unlawfully. As for the fiqh law related to lottery and lottery, there are differences of opinion in each circle. In establishing the law, it is guided by the quranic postulate, namely in al-Baqarah: 219, Q.S al-Maidah 90-91
\end{abstract}

Keywords: Lottery, Lottery, Masail Al-Fiqhiyyah

\begin{abstract}
ABSTRAK
Undian merupakan suatu kebiasaan yang sudah berlaku jauh sebelum Islam datang, namun undian yang berlaku pada masa jahiliyyah adalah untuk menentukan nasib baikburuk seseorang dan dilakukan di depan berhala-berhala mereka. Namun untuk kondisi saat ini, undian sering dilakukan dalam dunia perdagangan dengan tujuan agar para konsumen tertarik terhadap barang yang ditawarkannya. Lotere ataupun lotery peruntungan keduanya sangat ditentukan oleh nasib. Adapun penyelenggaraannya bisa dilakukan oleh perorangan, perusahaan ataupun lembaga. Tujuan keduanya biasanya ditunjukkan untuk mengumpulkan dana dalam upaya peningkatan pemasaran produk perdagangan. Jenis penelitian ini adalah penelitian kepustakaan (library research). Metode yang digunakan untuk menganalisisnya adalah content analysis (analisis isi), karena penelitian ini adalah document analysis (analisis dokumen). Pendekatan yang digunakan adalah maqasid syariah. Pada dasarnya lotere dan undian hampir sama, adapun perbedaan yang mendasar antara keduanya yaitu didalam lotere terdapat unsur judi
\end{abstract}

LABATILA: Jurnal Ilmu Ekonomi Islam - Volume 4, Nomor 1 (2020)

https://ejournal.iainu-kebumen.ac.id/index.php/lab 
yangdiharamkan, yaitu menang kalah atau untung rugi, sedangkan di dalam undian berhadiah yang berkembang saat ini tidak terdapat unsur rugi yang diharamkan sebagaimaa dalam judi. Dalam undian berhadiah tidak ada pihak yang dirugikan sehingga tidak ada istilah pihak satu memakan harta pihak lain secara tidak sah. Adapun hukum fiqhnya terkait dengan undian dan lotere terdapat perbedaan pendapat pada masingmasing kalangan. Dalam menetapkan hukum tersebut berpedoman pada dalil al-Quran yaitu pada al-Baqarah: 219, Q.S al-Maidah 90-91

Kata kunci: Undian, Lotere, Masail Al-Fiqhiyyah

\section{PENDAHULUAN}

Seperti yang kita ketahui, bahwa dalam kehidupan sangat banyak masalah yang muncul dalam masyarakat saat ini, bahkan untuk masa yang akan datang juga sangat mungkin muncul masalah-maslah yang lebih rumit. Untuk masalah-masalah yang akan datang mungkin tidak ditemukan hukumnya dalam kitab-kitab lama karena belum terjadi pada masyarakat dulu dan juga belum terpikirkan oleh para mujtahid pada saat itu. Oleh karena itu, tidak ada kevakuman dalam hukum fiqh, karena sepanjang sejarah setiap permasalahan fiqh yang muncul di kalangan masyarakat selalu ada penyelesaiannya.

Mengingat kehidupan yang semakin rumit sehingga banyaknya orang yang menghalalkan segala cara demi memenuhi kebutuhan hidupnya. Dalam masyarakat sekitar kita marak terjadi perjudian untuk mengadukan nasib mereka salah satunya dengan mengikuti undian dan lotere. Untuk itu, dalam paper ini penulis akan sedikit membahas mengenai masalah undian dan lotere yang nantinya diharapkan dapat memberikan pemahaman tentang hukum melakukan hal tersebut.

\section{METODE DAN PENDEKATAN}

Jenis penelitian ini adalah penelitian kepustakaan (library research). Metode yang digunakan untuk menganalisisnya adalah content analysis (analisis isi), karena penelitian ini adalah document analysis (analisis dokumen). Pendekatan yang digunakan adalah maqasid syariah. 


\section{PEMBAHASAN}

\section{Pengertian Undian dan Lotere}

Di dalam ensiklopedi Indonesia disebutkan bahwa lotere berasal dari bahasa Belanda loterij yang berarti undian berhadiah, undian nasib dan peruntungan. Sedangkan menurut kamus bahasa Inggris berasal dari kata lottery yang berarti undian. Dari dua pengertian tersebut baik undian dan lotere ataupun lotery peruntungan keduanya sangat ditentukan oleh nasib. Adapun penyelenggaraannya bisa dilakukan oleh perorangan, perusahaan ataupun lembaga. Tujuan keduanya biasanya ditunjukkan untuk mengumpulkan dana dalam upaya peningkatan pemasaran produk perdagangan.

Sedangkan undian merupakan suatu kebiasaan yang sudah berlaku jauh sebelum Islam datang, namun undian yang berlaku pada masa jahiliyyah adalah untuk menentukan nasib baik buruk seseorang dan dilakukan di depan berhala-berhala mereka. Namun untuk kondisi saat ini, undian sering dilakukan dalam dunia perdagangan dengan tujuan agar para konsumen tertarik terhadap barang yang ditawarkannya.

Dengan demikian pada dasarnya undian dan lotere pada hakikatnya mempunyai makna yang sama, akan tetapi pengertian dan praktek yang berkembang di masyarakat sangat berbeda. Lotere dipandang sebagai judi sedangkan undian tidak.Karena terdapat perbedaan pendapat mengenai pandangan antara undian dan lotere, apakah termasuk judi atau tidak, maka ada baiknya jika kita pahami kembali pengertian dari judi.

Judi adalah permaianan yang mengandung unsur taruhan yang dilakukan oleh dua orang atau lebih yang bertujuan untuk mencari nasib atau peruntungan. Dalam hal ini tentu akan ada pihak yang menang dan ada pihak yang kalah.Ketentuannya, Semua taruhan yang bertujuan untuk mengadu nasib yang sifatnya untung-untungan dilarang keras oleh agama sebagaimana firman Allah Swt dalam Q.S. Al-Maidah ayat 90-91: "Hai, orang-orang yang beriman sesungguhnya khamar, berjudi, berkorban untuk berhala, mengundi nasib dengan anak panah adalah perbuatan keji dan termasuk perbuatan syetan.Maka jauhilah perbuatan itu agar kamu mendapat 
keberuntungan.Sesungguhnya syetan hendak menimbulkan permusuhan dan kebencian diantara kamu lantaran khamar dan berjudi dan menghalangi kamu dari mengingat Allah dan solat, maka berhentilah kamu dari pekerjaan itu."

Berdasarkan ayat dan pernyataan dia atas, maka sudah jelas bahwa judi termasuk perbuatan yang diharamkan karna didalamnya mengandung unsur kekejian adanya campur tangan syetan dan dapat merugikan salah satu pihak yang ikut didalamnya.Judi merupakan perbuatan hukum yang dilarang dalam syariah berdasarkan Al-Qur'an dan sunah. ${ }^{1}$

\section{Jenis-Jenis Undian}

Ditinjau dari sudut manfaat dan mudaratnya ulama madzab Hanafi, Maliki, Hambali dan Syafi'i membagi undian menjadi atas dua bagian, yaitu undian yang tidak mengandung mudarat atau kerusakan dan undian yang mengandung mudarat dan tidak mengakibatkan kerugian. Adapun undian yang mengandung mudarat atau kerusakan ada dua macam yaitu :

a. Undian yang mengandung kerugian finansial pihak-pihak yang diundi. Dengan kata lain antara pihka-pihak yang diundi terdapat unsur-unsur untung-rugi, yakni jika di satu pihak ada yang mendapat keuntungan, maka dipihak lain ada yang merugi dan bahkan menderita kerusakan mental, biasanya manfaat yang diraihnya jauh lebih kecil dari pada kerugiannya.

b. Undian yang hanya menimbulkan kerugian atau kerusakan bagi dirinya sendiri, yaitu berupa kerusakan mental.Manusia menggantungkan nasib, rencana,pilihan dan aktifitasnya kepada para pengundi nasib atau peramal, sehingga akal pikirannya menjadi labil kurang percaya diri dan berfikir tidak realistik.Undian semacam disebutkan dalam Al-Qur'an disebut azlam (Q.S Al Maidah ayat 90).

Sedangkan undian yang tidak mengandung atau menimbulkan mudarat dan tidak mengakibatkan kerugian, baik bagi pihak-pihak yang diundi maupun pihak pengundi sendiri para pelakunya hanya mendapatkan keuntungan disatu pihak dan pihak lain tidak mendapat apa-apa akan tetapi tidak menimbulkan kerugian.Yang termasuk dalam katagori ini ialah segala macam undian 
berhadiah. Menurut Ibrahim Hosen undian berhadiah adalah salah satu cara untuk menghimpun dana yang digunakan untuk proyek kemanusiaan dan sosial. $^{2}$ Seperti segala macam undian yang berhadiah dari perusahaanperusahaan dengan motif promosi atas barang produksinya, undian untuk mendapatkan peluang tertentu (karena terbatasnya peluang tersebut) seperti undian untuk berangkat ibadah haji dengan Cuma-Cuma dan undian untuk menentukan giliran arisan.Termasuk juga dalam kategori ini bentuk undian dalam kategori prioritas urutan dalam perlombaan baik olahraga maupun kesenian.

\section{Bentuk-Bentuk Undian}

a. Bentuk undian yang diperbolehkan

Undian yang diperbolehkan yaitu ketika sebuah toko menyelenggarakan undian berhadiah bagi pelanggan atau pembeli yang nilai total belanjanya mencapai $\mathrm{Rp} 50.000,00$ dengan janji hadiah seperti itu, toko bisa menyedot pembeli lebih besar, misalnya 2 milyar dalam setahun.Pertambahan keuntungan ini bukan karena adanya kontribusi dari pelanggan atau pembeli sebagai syarat ikut undian, melainkan dari bertambahnya jumlah mereka.

Hadiah yang dijanjikan sejak awal memang sudah dipersiapakan dananaya meskipun pihak toko tidak mendapatkan keuntungan yang lebih, hadiah tetap diberikan maka dalam masalah hal ini tidaklah disebut sebagai perjudian karena konsumen atau pembeli sama sekali tidak dirugikan dimana barang belanja yang mereka dapatkan dengan uang itu memang sebanding dengan harganya.

Sedangkan menurut fiqih madzab Syafi'i terdapat tiga macam taruhan yang dibenarkan oleh agama Islam yaitu: apabila yang mengeluarkan barang atau harta yang dipertaruhkan adalah pihak tiga,

\footnotetext{
${ }^{1}$ Jaih Mubarok, dkk, Fikih Mu'amalah Maliyah, (Bandung: Simbiosa Rekatama Media), 2017, hlm. 324

${ }^{2}$ Ahmad Warson Munawwar, Kamus Munawwar,Yogyakarta;PT al Munawwir Krapyak,1984,hlm 1194.
} 
taruhan yang bersifat sepihak, dan taruhan yang dilakukan oleh dua orang atau lebih dengan ketentuan siapa saja yang kalah harus membayar atau memberikan sesuatu kepada yang menang, akan tetapi cara ini harus dengan mukhallil (yang menghalalkan).

b. Bentuk undian yang dilarang

Praktik undian berhadiah yang dilarang adalah undian berhadiah yang mensyaratkan peserta untuk membayar biaya tertentu, baik langsung maupun tidak langsung seperti membayar melalui pulsa, telephon premium call (diatas taraf biasa) dimana pihak penyelenggara akan menerima sejumlah uang tertentu dari para peserta, lalu hadiah diambilkan dari sejumlah uang yang terkumpul dari pemasukan premium call, maka ini termasuk kategori judi dan undian seperti ini haram hukumnya meski diberi nama apapun letak judinya terlihat pada harga yang lebih dari tarif SMS biasa.

\section{Hukum Undian dan Lotere}

Terdapat beberapa pendapat mengenai hukum adanya undian dan lotere

a. Rasyid Ridha

Beliau menerangkan bahwa sebagian bahaya dari perjudian adalah dapat merusak pendidika dan akhlak, juga dapat melemahkna potensi akal pikiran, dan juga mendorong kepada hal negatif. Beliau juga menjelaskan bahwa dalil yang mengharamkan semua perjudian tidaklah diragukan lagi. Hanya saja, menurut beliau ada lotere atau undian yang diselenggarakan pemerintah atau lembaga sosial lainnya yang semata-mata untuk menghimpun dana demi kepentingan umum atau kemaslahatan masyarakat. Seperti untuk mendirikan rumah sakit, sekolah, bahkan unuk meringankan beban fakir miskin.

Jadi, jika dilihat dari pendapat Rasyid Ridha tersbut beliau tidak mengharamkan undian jika untuk kepentingan umum, dan tidak ada yang 
dirugikan di dalamnya. ${ }^{3}$ Karena hal tersebut lebih banyak mudharatnya daripada manfaatnya. Sebaliknya apabila undian atau lotere tersebut dilakukan bukan untuk kepentingan umum, maka undian atau lotere tersebut diharamkan.

b. Hasan

Beliau berpendapat, bahwa mengadakan lotere atau membelinya adalah terlarang. Namun menerima atau meminta bagian dari uang lotre adalah perlu atau bahkan harus. Karena apabila tidak diambil, uang tersebut akan jatuh ke tangan orang lain, yang dapat merusak kita.

Dari pendapat tersebut, maka dari satu sisi lotere tersebut dilarang, akan tetapi jika dilihat dari sisi lain , jika dilaksanakan juga, seperti pada pemerintahan (Departemen Sosial), maka dama dari lotre tersebut dapat diambil agar tidak diambil pihak lain yang pemanfaatannya dapat merugikan masyarakat.

\section{c. Nahdlatul Ulama}

Ada sebuah praktik jual beli dalam organisasi yang dilakukan melalui jalan arisan. Peserta merupakan seluruh anggota organisasi. Disebut arisan karena pihak yang mendapatkan barang adalah yang namanya keluar dalam undian (qar'un).

Mekanisme yang dilakukan adalah dengan jalan semua peserta menyetorkan sejumlah uang ke bendahara, misalnya 5.000 rupiah dengan jumlah peserta sebanyak 100 orang. Setelah uang terkumpul semua, lalu ketua organisasi mengundinya. Nomor yang keluar berperan selaku pihak yang mendapatkan seluruh uang itu Akan tetapi, uang diberikan tidak berupa uang, melainkan jenis barang tertentu yang sudah disepakati oleh peserta sebelumnya. Sebut misalnya minyak goreng.

\footnotetext{
${ }^{3}$ https://www.academia.edu. Dikutip pada 8 Oktober 2020 pukul 23.00
} 
Harga eceran minyak goreng Merk $\mathrm{X}$ adalah 10 ribu rupiah per bungkus dan harga kulaknya sebesar 9 ribu rupiah per bungkus. Peserta sepakat bahwa pengurus organisasi yang belanja. Jika pengurus organisasi belanja dengan harga kulak, maka dia untung sebesar seribu rupiah. Selisih ini lalu dimasukkan sebagai kas organisasi. ${ }^{4}$

Dalam menghidupi sebuah organisasi, kadang dibutuhkan kecakapan dari seorang pemimpin. Salah satu kecakapan itu adalah berusaha menghasilkan dana organisasi. Akhirnya dilakukanlah berbagai upaya agar ada pemasukan, syukur bila dana itu kemudian menjadi dana produktif melalui usaha produktif seperti jual beli. Perlu diketahui bahwa hukum asal muamalah jual beli adalah boleh selagi tidak ditemukan illat (penyebab) keharaman. Hal ini didasarkan pada ayat hadis dan ayat al-qur'an berikut :

"Nabi Muhammad SAW beliau bersabda: "Allah SWT berfirman: 'Aku adalah pihak ketika dari dua orang yang bersekutu selagi tidak saling mengkhianati. Bila salah satunya telah berbuat khianat kepada sahabatnya, maka Aku keluar dari keduanya." HR. Abu Dawud

"Dan sesungguhnya kebanyakan dari orang-orang yang berserikat itu sebahagian mereka berbuat zalim kepada sebahagian yang lain, kecuali orang orang yang beriman dan mengerjakan amal yang saleh; dan amat sedikitlah mereka ini." (QS Shâd [38]: 24)

d. Majelis Tarjih Muhammadiyah

Dalam Majelis Tarjih Muhammadiyah dalam kitab beberapa masalah cetakan ke-5 Tahun 1373 H/ 1954 M, disebutkan "Lotere itu terdiri dari tiga unsur: membeli, meminta keuntungan, dan mengadakannya. Lotere dengan ketigaunsur itu termasuk masalah musytaihat." "5

Membeli lotere mudharatnya lebih besar daripada manfaatnya, oleh karena itu hukumnya haram. Sedangkan mengadakan dan meminta

\footnotetext{
${ }^{4}$ https://islam.nu.or.id/post/read/110625/hukum-lotre-untuk-kemaslahatan-organisasi. Diakses 8 November 2020 pukul 21.30

${ }^{5}$ M. Ali. Hasan,MASAIL FIQHIYAH Zakat, Pajak, Asuransi, dan Lembaga Keuangan,Jakarta: PT Raja Grafindo Persada,2000.Hlm.102.
} 
keuntungan dari lotere, penetapan hukumnya diserahkan kepada Lajnah Tarjih masing-masing cabang. Dari sini belum ada kebulatan penadapat dalam penetapan hukum. Sehingga kemudian Majelis Tarjih Muhammadiyah membicarakn kembali masalah Lotto dan Nalo, dan kemudian menghasilkan keputusan bahwa Lotto dan Nalo hukumnya adalah haram karena lebih banyak madharatnya, walaupun ada sedikit manfaatnya. Sebagaimna Firman Allah "Mereka bertanya kepadamu tentang khamr dan judi. Katakanlah pada keduanya itu terdapat dosa besar dan bebrapa manfaat bagi manusia, tetapi dosanya tu lebih besar dari manfaatnya " (Q.S. al-Baqarah: 219) ${ }^{6}$

e. Syekh Ahmad Surkati (al-Irsyad)

Beliau berpendapat bahwa lotere bukanlah judi karena bertujuan untuk menghimpun dana yng akan disumbangkan untuk kegiatan-kegiatan sosial dan juga kegiatan kemanusiaan. Beliau berpendapat, bahwa unsur negatifnya ada, akan tetapi sangat kecil apabila dibandingkan dengan manfaatnya.

f. DR. Fuad Muchammad Fachruddin

DR. Fuad Muhammad Fachruddin berpendapat bahwa lotere tidak termasuk dalam kategori judi yang diharamkan. Beliau juga mengatakan

"pembeli lotere apabila maksud dan tujuannya hanya menolong dan mengharapkan hadiah, maka tidaklah terdapat dalam perbuatan itu satu perjudian. Apabila tujuannya itu tertentu semata-mata mendapatlan hadiah, ini pun tidak tergolong dalam soal perjudian, sebab kaidah perjudian sebagaimana yang disebutkan oleh Imam Syafi'i ialah kedua belah pihak yang berhadap-hadapan masingmasing menghadapi kemenangan atau kekalahan"7

Dari beberapa pendapat tersebut, belum ada kesepakatan dari argumentasi masing-masing. Berarti masalah tersebut termasuk dalam kategori masalah ijtihadi. Jika dilihat sepintas dari tujuan lotere adalah

6 Ibid. Hlm.103

${ }^{7}$ Ibid 
untuk menghimpun dana yang akan digunakan untuk keperluan sosial memang cukup baik, akan dampaknya juga perlu diperhatikan dan dipertimbangkan:

Pertama dana hasil penjualan lotere terserap dari anggota masyarakat yang status ekonominya lemah, seperti tukang becak, pedagang kecil, sopir, bahkan orang-orang yang tidak mempunyai penghasilan tetap. Mereka berharap akan menang undian lotere tersbut. Jadi uang yang mereka hasilkan dari susah payah justru dihabiskan untuk membeli hal-hal yang mudharat.

Kedua, lotere dapat merusak jiwa dan pendidikan anakanak generasi penerus, dengan cara membiasakan hidup untunguntungan, mengadu nasib untuk dan menghadapi masa depan dengan langkah yang tidak pasti. ${ }^{8}$

Selain bahaya tersebut, juga terdapat bahaya yang menyangkut dengan kerusakan akidah karena tidak sedikit orang yang datang ke dukun untuk mencari nomor yang tepat. Padahal dukun tersebut tidak membeli lotere dan menjadi kaya. Apabila lotere dianggap sama dengan judi, maka hukumnya dalah haram dan dosa ketika melakukannya.

Firman Allah dalam Q.S. al-Maidah 90-91

"menghindari kerusakan-keruakan harus didahulukan dari pada menarik kebaikan-kebaikan" "menutup pintu/jalan (kerusakan)"

Dari penjelasan tersebut, maka jelaslah bahwa mencegah perbuatan yang tidak baik atau merusak sebelum terjadi, adalah lebih baik daripada memperbaikinya ketika sudah terlanjur terjadi.

${ }^{8}$ Ibid. Hlm.105 


\section{KESIMPULAN}

Pada dasarnya lotere dan undian hampir sama, adapun perbedaan yang mendasar antara keduanya yaitu didalam lotere terdapat unsur judi yang diharamkan, yaitu menang kalah atau untung rugi, sedangkan di dalam undian berhadiah yang berkembang saat ini tidak terdapat unsur rugi yang diharamkan sebagaimaa dalam judi. Dalam undian berhadiah tidak ada pihak yang dirugikan sehingga tidak ada istilah pihak satu memakan harta pihak lain secara tidak sah.

Adapun hukum fiqhnya terkait dengan undian dan lotere terdapat perbedaan pendapat pada masing-masing kalangan. Dalam menetapkan hukum tersebut berpedoman pada dalil al-Quran yaitu pada al-Baqarah: 219, Q.S alMaidah 90-91 yang menjelaskan menganai masalah perjudian. Namun dalam kalangan masyarakat yang berkembang saat ini, lotere sering dianggap sebagai perjudian sehingga diharamkan, sedangkan undian bukan sebagi judi karena tidak ada pihak yang dirugikan.

\section{DAFTAR PUSTAKA}

Departemen Agama RI. Al-Quran \& Terjemah. Semarang: Toha Putra, 2005

H.Jaih Mubarok,dkk, Fikih Mu'amalah Maliyah, Bandung: Simbiosa Rekatama, 2017

M. Ali. Hasan, Masail Fiqhiyah Zakat, Pajak, Asuransi, dan Lembaga Keuangan,Jakarta: PT Raja Grafindo Persada, 2000.

Muhammad bin Shalih Al Munajjid, Haram Tapi Disukai,Solo: Nabawi Publishing, 2012.

Muhammad Yusuf, Masail Fiqhiyyah Memahami Permasalahan Kontemporer, Jakarta : Gunadarma Ilmu, Cet. II, 2017.

Zuhdi, Masjfuk. Masail Fiqhiyah. Cet. ke-IX; Jakarta: PT.Toko Gunung Agung, 1996.

Pusat Bahasa Departemen Pendidikan Nasional. Kamus Besar Bahasa Indonesia. Edisi Ketiga, Cet. IV; Jakarta: Balai Pustaka, 2007

Majalah Bulanan Tabligh. Konsultasi: Hukum SMS dan Kuis Berhadiah. Jakarta: Majelis Tabligh dan dakwah Khusus PP Muhammadiyah, September, 2006

https://islam.nu.or.id/post/read/110625/hukum-lotre-untuk-kemaslahatanorganisasi

http://eprints.walisongo.ac.id

https://www.academia.edu 